\title{
Undergraduate Medical Students' Perspective of Online Lecture
}

\author{
Indah Puspasari Kiay Demak ${ }^{1,2^{*}}$, Nur Syamsi ${ }^{3}$, Andi Alfia Muthmainnah Tanra \\ ${ }^{1}$ Medical Education Unit, Medical Faculty, Tadulako University \\ ${ }^{2}$ Public Health Department, Medical Faculty, Tadulako University \\ ${ }^{3}$ Pharmacology Department, Medical Faculty, Tadulako University \\ *Corresponding author: sashkata@yahoo.com
}

\begin{abstract}
Online lectures provide easier and more effective access, a wider amount of information, autonomy and reflective thinking, and flexibility. This study aims to assess medical students' perspectives on the online lecture. It is a descriptive observational study that was conducted from March to June 2019. The research subjects were 87 second-year medical students of Tadulako University. After conducting online learning, students were given a questionnaire regarding the online lecture process. The results showed that the application could be operated easily, although few students still have audio, video, and internet connection problems. Some students had difficulty concentrating and hard to understand the material. This problem can be overcome by providing online learning training to lecturers to engage students in the online learning process. Also, many students experience advantages, namely flexible time management, cost -effective and increasing motivation.
\end{abstract}

Keywords: Online lecture, undergraduate, medical student

\section{INTRODUCTION}

Electronic (e) or online learning can be defined as using technology and electronic media to convey, support, and enhance learning and teaching by involving communication between students and teachers using online content [1,2]. Historically, there are two common e-learning methods: distance learning and computer-assisted instruction with the internet as an integration technology in these two modes. Distance learning uses information technology to convey instructions to students, while computer-assisted instruction uses computers to help deliver learning and teaching. [2].

The swift development of technology over the last few decades, with computer versions available widely in various forms: tablets, mobile phones, and laptops, is changing the educational approach and potentially improving health service delivery $[3,4]$. The integration of e-learning into medical education sustainably and consistently brings about a revolution in medical education, creates new learning experiences for students, resulting in the conventional method of face-to-face in lecture halls being rarely used $[2,4,5]$.
Online lectures provide more comfortable and more effective access, a broader amount of information, autonomy, reflective thinking, and flexibility, thereby enhancing individual student learning $[1,6]$. However, the transition from traditional learning to online learning is not without challenges [1]. The effectiveness of online learning is influenced by many factors, such as administrative problems, social interaction, academic skills, technical skills, student motivation, time and support for studies, technical problems, costs and access to the internet, and the design and arrangement of multimedia materials. These factors must be assessed, including the learning objectives, the nature of the learning materials' design, the evaluation of learning outcomes, to name some. [7]. This study aims to assess medical students' perspectives on online learning, especially online lectures.

\section{METHODS}

The research is a descriptive observational study that aims to determine students' opinions about online learning conducted from March to June 2019. The research subjects were 87 second-year medical students 
of Tadulako University.

Before the online learning process, students were given a short training on the procedure for online learning using a zoom program accompanied by a 90 minute practicum. Students get an online lecture on Pharmacology material for 100 minutes. Students have received worksheets totaling five numbers of relevant questions to the previous lecture material before the class. The worksheets must be done by students in groups and will be presented during the next lecture.

After conducting online learning, students are given an opinion questionnaire regarding the online lecture process. The questionnaire consisted of 20 question items divided into two parts, namely the experience of using the zoom application and the concentration of online lectures.

\section{RESULTS}

Table 1 Subjects' characteristic

\begin{tabular}{|l|l|}
\hline Characteristic & \multicolumn{1}{|c|}{ Total } \\
\hline Sex & \\
Male & $30(34.5 \%)$ \\
Female & $57(65.5 \%)$ \\
\hline Age & \\
17 & $1(1.1 \%)$ \\
18 & $1(1.1 \%)$ \\
19 & $30(34.5 \%)$ \\
20 & $54(62.1 \%)$ \\
21 & $1(1.1 \%)$ \\
\hline
\end{tabular}

Students who become subjects consist of women $(65.5 \%)$ and men (34.5\%). Most of the participants were 20 years $(62.1 \%)$. All subjects were categorized as adults.

Table 2 Descriptive data of the students' online learning process

\begin{tabular}{|c|c|c|c|}
\hline No & Questions & $\begin{array}{c}\mathbf{Y e} \\
\mathrm{s}\end{array}$ & No \\
\hline 1 & $\begin{array}{l}\text { I have used the Zoom } \\
\text { application }\end{array}$ & $\begin{array}{l}85 \\
(97.7 \%)\end{array}$ & $2(2.3 \%)$ \\
\hline 2 & $\begin{array}{l}\text { I have used the } \\
\text { Webinar } \\
\text { application }\end{array}$ & $5(5.7 \%)$ & $\begin{array}{l}82 \\
(94.3 \%)\end{array}$ \\
\hline 3 & $\begin{array}{l}\text { I have the Zoom app on } \\
\text { my cellphone }\end{array}$ & $\begin{array}{l}80(92 \\
\%)\end{array}$ & $7(8 \%)$ \\
\hline 4 & $\begin{array}{l}\text { I have the Zoom d } \\
\text { application on my } \\
\text { laptop / PC }\end{array}$ & $\begin{array}{l}69 \\
(79.3 \%)\end{array}$ & $\begin{array}{l}18 \\
(20.7 \%)\end{array}$ \\
\hline 5 & $\begin{array}{l}\text { I am ready to attend } \\
\text { online learning with } \\
\text { independent mobile } \\
\text { and } \\
\text { internet facilities }\end{array}$ & $\begin{array}{l}75 \\
(86.2 \%)\end{array}$ & $\begin{array}{l}12 \\
(13.8 \%)\end{array}$ \\
\hline \multicolumn{4}{|c|}{ Use of the Zoom Application } \\
\hline 6 & $\begin{array}{l}\text { Applications can be } \\
\text { operated easily }\end{array}$ & $\begin{array}{l}87 \\
(100 \%)\end{array}$ & 0 \\
\hline
\end{tabular}

\begin{tabular}{|c|c|c|c|}
\hline 7 & $\begin{array}{l}\text { The audio quality is } \\
\text { good during the online } \\
\text { learning } \\
\text { process }\end{array}$ & $\begin{array}{l}79 \\
(90.8 \%)\end{array}$ & $8(9.2 \%)$ \\
\hline 8 & $\begin{array}{l}\text { The video quality is } \\
\text { good } \\
\text { during the online } \\
\text { learning process }\end{array}$ & $\begin{array}{l}83 \\
(95.4 \%)\end{array}$ & $4(4.6 \%)$ \\
\hline 9 & $\begin{array}{l}\text { There is no trouble in } \\
\text { internet } \\
\mathrm{k} \text { networ } \\
\text { the } \\
\text { online learning process }\end{array}$ & $\begin{array}{l}57 \\
(65.5 \%)\end{array}$ & $\begin{array}{l}30 \\
(34.5 \%)\end{array}$ \\
\hline 10 & $\begin{array}{l}\text { Online learning } \\
\text { process still need to } \\
\text { use other learning } \\
\text { management } \\
\text { systems/applications } \\
\text { in online learning } \\
\text { (Moodle, } \\
\text { Edmodo, etc.) }\end{array}$ & $\begin{array}{l}46 \\
(52.9 \%)\end{array}$ & $\begin{array}{l}41 \\
(47.1 \%)\end{array}$ \\
\hline \multicolumn{4}{|c|}{$\begin{array}{l}\text { Concentration and other benefit in online } \\
\text { learning }\end{array}$} \\
\hline \multirow[t]{2}{*}{11} & $\begin{array}{lcc}\text { During } & \text { lectures } & \text { and } \\
\text { plenary } & \text { session, } \\
\text { can }\end{array}$ & $40(46 \%)$ & $47(54 \%)$ \\
\hline & concentrate fully & & \\
\hline 12 & $\begin{array}{l}\text { I can thoroughly } \\
\text { understand the } \\
\text { material discussed } \\
\text { during plenary } \\
\text { session }\end{array}$ & $\begin{array}{l}33 \\
(37.9 \%)\end{array}$ & $\begin{array}{l}54 \\
(62.1 \%)\end{array}$ \\
\hline 13 & $\begin{array}{l}\text { I find online learning } \\
\text { more practical } \\
\text { because the lecture } \\
\text { time is more flexible }\end{array}$ & $\begin{array}{l}73 \\
(83.9 \%)\end{array}$ & $\begin{array}{l}14 \\
(16.1 \%)\end{array}$ \\
\hline 14 & $\begin{array}{l}\text { With online learning, I } \\
\text { can do other important } \\
\text { things at the same time }\end{array}$ & $\begin{array}{l}57 \\
(65.5 \%)\end{array}$ & $\begin{array}{l}30 \\
(34.5 \%)\end{array}$ \\
\hline 15 & $\begin{array}{l}\text { I prefer online } \\
\text { learning because I can } \\
\text { do both attend lecture } \\
\text { while reading } \\
\text { textbooks or looking } \\
\text { for literature on the } \\
\text { internet to confirm or } \\
\text { look deeper about the } \\
\text { course material }\end{array}$ & $\begin{array}{l}69 \\
(79.3 \%)\end{array}$ & $\begin{array}{l}18 \\
(20.7 \%)\end{array}$ \\
\hline 16 & $\begin{array}{l}\text { I prefer online } \\
\text { learning because I can } \\
\text { share my time with } \\
\text { organizational } \\
\text { activities }\end{array}$ & $60(69 \%)$ & $27(31 \%)$ \\
\hline 17 & $\begin{array}{l}\text { I prefer online learning } \\
\text { because it can save } \\
\text { time and money }\end{array}$ & $\begin{array}{l}72 \\
(82.8 \%)\end{array}$ & $\begin{array}{l}15 \\
(17.2 \%)\end{array}$ \\
\hline
\end{tabular}




\begin{tabular}{|c|c|c|c|}
\hline 18 & $\begin{array}{l}\text { I prefer online } \\
\text { learning because I can } \\
\text { choose a comfortable } \\
\text { place and conducive } \\
\text { situation to listen to } \\
\text { lectures }\end{array}$ & $\begin{array}{l}74 \\
(85.1 \%)\end{array}$ & $\begin{array}{l}13 \\
(14.9 \%)\end{array}$ \\
\hline 19 & $\begin{array}{l}\text { I prefer } \\
\text { learning because I can } \\
\text { still attend lectures } \\
\text { even though my body } \\
\text { condition is not } \\
\text { optimal }\end{array}$ & $80(92 \%)$ & $7(8 \%)$ \\
\hline 20 & $\begin{array}{l}\text { Online learning } \\
\text { motivate me to study } \\
\text { independently }\end{array}$ & $\begin{array}{l}68 \\
(78.2 \%)\end{array}$ & $\begin{array}{l}19 \\
(21.8 \%)\end{array}$ \\
\hline
\end{tabular}

Based on the results in table 2, it is found that not all students have ever used the zoom program independently. There are two students $(2.3 \%)$ who have never operated their zoom. Practicum using zoom before the lecture is not counted. Moreover, two students have used the webinar program. $92 \%$ of subjects used a smartphone to operate the zoom, and $79.3 \%$ used laptops or personal computers.

All students thought that the zoom application could be operated easily. Although $9.2 \%$ of students still have audio problems and $4.6 \%$ of students have problems with video applications. Furthermore, as much as an internet connection still constrains $34.5 \%$.

$86.2 \%$ of students felt that they were ready with the online learning model, although $54 \%$ of students admitted that they had difficulty concentrating during the lecture so that it had an impact on understanding the material, $62.1 \%$ of students complained that they were still unable to understand. Based on the data obtained from additional reasons, students find it difficult to concentrate due to technical problems, such as muted audio settings, slow internet connection, inadequate audio, and video quality. Other students feel unable to concentrate if they do not see the lecturer face to face. Students who find it difficult to understand online learning say that this is because they have difficulty focusing. It is different if they are in class directly. The environment created when students can meet lecturers directly creates a different atmosphere compared to only through gadgets.

$74.7 \%$ of students like it because lectures can be followed even though the students are outside campus. According to students, with online learning, students can be more flexible in time management $(83.9 \%)$, can do other important things $(65.5 \%)$, and can attend lectures while reading the relevant literature $(79.3 \%)$. Also, students argued that they could share their study time with organizations $(69 \%)$.
Another positive thing raised by students is that with online learning, sick students can continue to attend courses $(92 \%)$, cheaper costs $(82.8 \%)$, and students can choose for themselves a comfortable place to attend lectures $(85.1 \%) .78 .2 \%$ of students said they were sufficiently motivated to attend online lectures.

\section{DISCUSSION}

\subsection{Zoom Application Use}

Research in the medical and nonmedical fields has consistently shown that students are very satisfied with elearning. The satisfaction level of the e- learning method is higher than the conventional method in terms of ease of use and access to applications, navigation, and userfriendly application interface design [2]. The results showed that all students thought the zoom application was easy to operate. Accessibility of content through gadgets such as cellphones complements the ease of access that students like [8]. As obtained from this study, $92 \%$ of the subjects used cellphones to operate the Zoom application. However, from several studies, it was also stated that there were students who were not familiar with e-learning because their basic information technology knowledge and skills were still lacking [8]. This study results show that $9.2 \%$ of subjects were still constrained by audio, and $4.6 \%$ were constrained by video in the application.

\subsection{Concentration \& Online Learning}

Previous studies report that students prefer e- learning because they gain more knowledge by understanding the subject better, acquire better skills, and feel more satisfied because of the ease of accessibility, flexibility, costeffectiveness, and broader opportunities for study $[9,10]$. Flexibility in e-learning means that the learning process can be implemented under the students' conditions, regardless of geographic location, which does not require a specific time or binding schedule, and it is easy to access the material. It is a significant benefit compared to conventional lecture methods [8,10-12]. Based on research, $86.2 \%$ of students feel ready for an online learning model. In terms of flexibility, $74.7 \%$ of students like it because lectures can be followed even though they are outside the campus. According to students, with online learning, students can be more flexible in time management $(83.9 \%)$, while doing other important things $(65.5 \%)$, can attend lectures while reading the relevant literature $(79.3 \%)$. Furthermore, even students who are sick can still attend lectures (92\%). Also, students argued that indirectly, they could share their study time with organizations (69\%).

Another study reported that students' dissatisfaction with the e-learning method was caused by a lack of interaction with teachers and in-depth group discussions to clarify concepts for complex topics [10]. Likewise, from this study, it was found that students admitted that it was difficult to concentrate if they did not see the 
lecturer directly, $54 \%$ had difficulty concentrating during the lecture, $62.1 \%$ of students complained that they were still unable to understand the material being discussed so that it had an impact on understanding the material.

\subsection{Motivation}

Several blended learning studies use Kahoot! and Edmodo, it was found that blended learning fosters student motivation and encourages dynamic participation in the context of teaching and learning [9]. Studies in students studying radiology courses through blended learning feel more satisfied, as shown by post-course satisfaction assessments. A positive attitude towards blended learning in terms of effectiveness is $87.5 \%$, motivation $91.7 \%$, and active involvement $75 \%$ [5]. As in this study, the results obtained that $78.2 \%$ of students said they were motivated to attend online lectures.

\subsection{Cost-effective}

Research on the design and implementation of blended learning in medicine in Iran shows that this educational method can be cost-effective and is recommended for adoption. The results also showed that students were significantly more satisfied with learning through the blended learning method than traditional (face-to-face) education $[10,12,13]$. The research results found that students prefer online learning because it can save costs $(82.8 \%)$.

\section{CONCLUSION}

Medical students of Tadulako University are ready to implement online learning. Although with some technical obstacles that can be overcome by providing facilities from the faculty. The shortcomings of students in understanding the material can be overcome by providing online learning training to lecturers to engage students in the online learning process. In addition, there are several benefits that students can achieve from studying online, namely flexible time management, cost-effective and increasing motivation.

\section{ACKNOWLEDGMENT}

This research was approved by the ethics committee of The Faculty of Medicine Tadulako University (No. 2553/UN28.1.30/KL/2019).

\section{REFERENCES}

[1] D. O'Doherty, M. Dromey, J. Lougheed, A. Hannigan, J. Last, D. McGrath, Barriers and solutions to online learning in medical education - an integrative review, BMC Med. Educ. 18(1)
(2018) 130. DOI: https://doi.org/10.1186/s12909018-1240-0

[2] K. Zehry, N. Halder, L. Theodosiou, E- Learning in medical education in the United Kingdom, Procedia - Soc. Behav. Sci. 15 (2011) 3163-3167. DOI : https://doi.org/10.1016/j.sbspro.2011.04.265

[3] S. Barteit, A. Jahn, S. S. Banda, T. Bärnighausen, A. Bowa, G. Chileshe, et al., E- learning for medical education in sub-Saharan Africa and lowresource settings: Viewpoint, J. Med. Internet. Res. 21(1) (2019) e12449. DOI: https://doi.org/10.2196/12449

[4] K. J. Kim, G. Kim, Development of e-learning in medical education: 10 years' experience of Korean medical schools, Korean J. Med. Educ. 31(3) (2019) 205-214. DOI https://dx.doi.org/10.3946\%2Fkjme.2019.131

[5] S. Zafar, S. Safdar, A. N. Zafar, Evaluation of use of e-Learning in undergraduate radiology education: A review, Eur. J. Radiol. 83(12) (2014) 2277-2287. DOI https://doi.org/10.1016/j.ejrad.2014.08.017

[6] R. Khasawneh, K. Simonsen, J. Snowden, J. Higgins, G. Beck, The effectiveness of e- learning in pediatric medical student education, Med. Educ. Online 21(1) (2016) 8-11. DOI : https://doi.org/10.3402/meo.v21.29516

[7] L. Pei, H. Wu, Does online learning work better than offline learning in undergraduate medical education? A systematic review and metaanalysis, Med. Educ. Online 24(1) (2019) $1666538 . \quad$ DOI https://doi.org/10.1080/10872981.2019.1666538

[8] K. Regmi, L. Jones, A systematic review of the factors - enablers and barriers - affecting elearning in health sciences education, BMC Med. Educ. 20(91) (2020). DOI : https://doi.org/10.1186/s12909-020-02007-6

[9] U. K. Masrom, N. A. N. M. Alwi, Teaching With Technology In Classrooms: Implementing Blended Learning, in: The European Proceedings of Social \& Behavioural Sciences (IEBMC), Kuantan, Pahang, Malaysia, 2017, pp. 932-940. DOI https://dx.doi.org/10.15405/epsbs.2018.07.02.98

[10] S. K. Dhir, D. Verma, M. Batta, D. Mishra, Elearning in medical education in India, Indian Pediatr. 54(10) (2017) 871-877. DOI: https://doi.org/10.1007/s13312-017-1152-9

[11] R. Gaupp, J. Dinius, I. Drazic, M. Körner, Long-term effects of an e-learning course on patient safety: A controlled longitudinal study with medical students, PLoS One 14(1) (2019) 1-13. DOI https://doi.org/10.1371/journal.pone.0210947

[12] B. Means, Y. Toyama, R. Murphy, M. Bakia, K. Jones, Evaluation of Evidence-Based Practices 
in Online Learning: A Meta-Analysis and Review of Online Learning Studies, U.S. Department of Education, 2010.

[13] Z. Mirmoghtadaie, N. Kohan, D. Rasouli, Determination and Comparison of the Factors Related to Effective Blended Learning in Medical Sciences from the Viewpoints of Instructors and Learners, Adv. Med. Educ. Pract. 11 (2020) 205-214. DOI: https://dx.doi.org/10.2147\%2FAMEP.S239216 